\title{
English in the South of England
}

\section{Introduction to the special issue}

Early sociolinguistic studies in England were mainly conducted in the geographical South of the country, e.g. Trudgill in Norwich (1974), Cheshire in Reading (1982), Britain in the Fens (1997), and Kerswill and Williams in Milton Keynes (2000). However, around the turn of the millennium, interests shifted more and more towards investigating varieties in the North. The biennual Northern English workshop, and the edited volumes by Hickey (2015) and Beal and Hancil (2017) are witnesses of the increased research into variation and change processes in Northern English varieties.

Meanwhile, research in the South was dominated by the discussions around the nebulous term Estuary English (Rosewarne, 1984), and the two large-scale Multicultural London English projects by Jenny Cheshire and Paul Kerswill (e.g. Cheshire et al., 2011). As a result, for a long time, research of linguistic variation in other Southern English variety areas was more or less neglected (with the exception of extensive research by Dave Britain in the Fenlands). However, in the last decade we have seen some increasing interest in research on Southern varieties which is reflected in the number of research activities involving Southern English varieties. A workshop on historical and present-day aspects of Southern English was held at the University of Brighton in March 2014, and this was to run again at Cambridge University in 2015, and at University College London in 2016. Wright (2018) subsequently published an edited volume on linguistic research in the South of England.

In April 2017, we organised a language variation and change workshop at the University of Suffolk, which, once again, focused on Southern English varieties. We became aware that there is a young generation of linguists all working on variation and change in the South of England, and wanted to promote and foster this interest. Hence, plans were made to compile this special issue to showcase and draw attention to the diverse range of exciting work which is taking place in this much under-studied region.

The South is a diverse geographical area which can be divided into the South East and the South
West, and, within these broader categories, we can begin to distinguish more specific geographical areas. The South East, i.e. London and the Home Counties, is characterized by being the most populous area, with a diverse population and high mobility. This is true, in particular, for the well known 'commuter belt', that is high intensity regions of people commuting to London for work from surrounding areas (e.g. Britain, 2010). Hence, the South East is typically thought of as highly mobile, which, inevitably, has repercussions on language use. Large-scale dialect levelling, i.e. the reduction of dialect features, led much of the

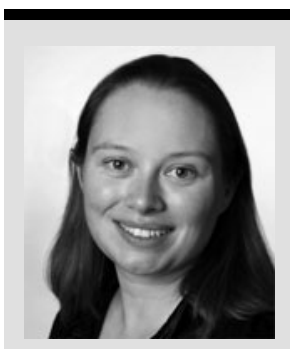

SANDRA JANSEN (iD is a Senior Lecturer in English linguistics at the University of Paderborn, Germany. Her research focuses on language variation and change, Cumbrian English, sociophonetics and variation in production and perception of L2 varieties of English.

Recently, she edited a volume on Sociolinguistics in England (Palgrave; with Natalie Braber) and a volume on Processes of Change: Studies in Late Modern and Present-Day English (John Benjamins; with Lucia Siebers).Email: sandra.jansen@ unipaderborn.de

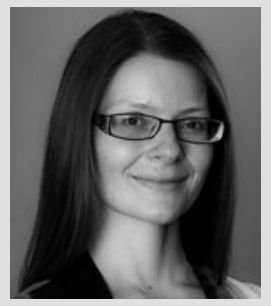

JENNY AMOS is Lecturer in English at the University of Suffolk. Her research focuses on the phonological modelling of language variation and change, particularly using varieties of East Anglian English. As a result, she is interested in both theoretical phonology and sociolinguistic variation, and is currently working on a number of projects relating to varieties in both Suffolk and North East Essex, as well as supervising PhDs relating to language use in business interactions and artificial language construction.Email: jennifer.amos@uos.ac.uk 
early discussion regarding Estuary English, and, while researchers such as Przedlacka (2001) and Torgersen and Kerswill (2004) show that variation exists within the South East, the notion of Estuary English has been adopted by the population due to extensive media coverage of the concept.

In addition, the South East is also associated with 'middle-class speech'. This may be considered influential in the process of levelling certain linguistic features, such as h-dropping and the loss of rhoticity, which have been stigmatized as working-class and farmer speech in this area (particularly in the second half of the $20^{\text {th }}$ century).

Another aspect which is somewhat related to the supralocal levelling of features is the diffusion of innovative features from London. Features, such as TH-fronting and L-vocalisation, which are now spreading across the South East, as well as across the North (e.g. Kerswill, 2003; Jansen, 2014), are said to originate in the East End of London.

Several articles in this special issue are dedicated to geolinguistic processes. The articles by Alderton, Britain et al., Jansen et al. and Butcher are all concerned with outcomes of dialect contact in the South of England. While Alderton investigates the perception of T-glottalling as innovation, Butcher studies the decrease of traditional East Anglian features. Britain et al. and Jansen et al. discuss innovation and obsolescence of dialect features in the area based on English Dialect App data.

The variety of Mersea Island English, North East Essex, has also been subject to high levels of contact in recent years. However, employing a sociophonological approach, Amos et al. re-examine the treatment of $(t, d)$-deletion. This paper argues for a separation of $(\mathrm{t})$ and $(\mathrm{d})$ as variables, and introduces the effects of intonation on deletion patterns, demonstrating the importance of considering phonological factors when designing sociolinguistic methodologies and analysis.

A special issue on the language use in the South of England necessarily needs to involve research on variation in the capital. For a long time, the working-class dialect of Cockney was associated with London's East End, but the last two decades have seen an increased interest in the contact-driven variety Multicultural London English Oxbury \& de Leeuw tap into this dynamic linguistic situation by investigating style-shifting in the FACE, PRICE and GOAT diphthongs by 11-year-old girls.

While research in London and the South East of England has a long tradition, other parts of the South, such as Cornwall, the westernmost county in the South of England, have been almost completely neglected. There is a long history of Cornish-English language contact, and members of the Cornish population are still proud of their Celtic roots. Sandow uses this background to study how people use lexical variation to create a Kernow identity. The construction of personae through enregistered features is a common facet of third wave studies, and Straw also uses this approach. She investigates how bards create a 'Forest Persona' in their dialect writing relating to the Forest of Dean area in Gloucestershire.

While the research presented in this special issue provides new insights into the linguistic South of England, more research is clearly needed. Little is known about the dialects in other urban and/or multicultural centers across the South, such as Canterbury, Plymouth, and Winchester, or, indeed, more rural areas where counter-urbanisation is either being resisted or promoted, due to transport and commercial developments. With this volume we would like to encourage and inspire linguists to engage in research within this diverse, but understudied area.

Sandra Jansen and Jenny Amos

\section{References}

Beal, J. \& Hancil, S. (eds.) 2017. Perspectives on Northern Englishes. Berlin: Mouton de Gruyter.

Britain, D. 1997. 'Dialect contact and phonological reallocation: "Canadian Raising" in the English Fens.' Language in Society, 26, 15-46.

Britain, D. 2010. 'Supralocal regional dialect levelling.' In C. Llamas \& D. Watt (eds.), Language and Identities. Edinburgh: Edinburgh University Press, pp. 193-204.

Cheshire, J. 1982. Variation in an English Dialect: A Sociolinguistic Study. Cambridge/New York: Cambridge University Press.

Cheshire, J., Kerswill, P., Fox, S. \& Torgersen, E. 2011. 'Contact, the feature pool and the speech community: The emergence of Multicultural London English.' Journal of Sociolinguistics, 15, 151-198.

Hickey, R. 2015 (ed.) Researching Northern English. Amsterdam/New York: John Benjamins.

Jansen, S. 2014. 'Salience effects in the north-west of England.' Linguistik Online 66, 91-110.

Kerswill, P. 2003. 'Dialect levelling and geographical diffusion in British English.' In D. Britain \&

J. Cheshire (eds.), Social Dialectology. In Honour of Peter Trudgill. Amsterdam/New York: John Benjamins, pp. 223-243.

Kerswill, P. \& Williams, A. 2000. 'Creating a new town koine: Children and language change in Milton Keynes.' Language in Society, 29, 65-116.

Przedlacka, J. 2001. 'Estuary English and RP: Some recent findings.' Studia Anglica Posnaniensia, 36, 35-50.

Rosewarne, David 1984. 'Estuary English.' Times Educational Supplement, 19 October. 
Torgersen E. \& Kerswill, P. 2004. 'Internal and external motivation in phonetic change. Dialect levelling outcomes for an English vowel shift.' Journal of Sociolinguistics, $8(1), 23-53$.
Trudgill, P. 1974. The Social Differentiation of English in Norwich. Cambridge: Cambridge University Press.

Wright, L. (ed.) 2018. Southern English Varieties Then and Now. Berlin: de Gruyter Mouton. 